\title{
First ornithopod remains from the Bajo de la Carpa Formation (Santonian, Upper Cretaceous), northern Patagonia, Argentina
}

\author{
Penélope Cruzado-Caballero ${ }^{\mathrm{a}}{ }^{*}$, Leonardo S. Filippi ${ }^{\mathrm{b}}$, Ariel H. Méndez ${ }^{\mathrm{a}}$, \\ Alberto C. Garrido ${ }^{\mathrm{c}, \mathrm{d}}$, Ignacio Díaz-Martínez ${ }^{\text {a }}$ \\ a Instituto de Investigación en Paleobiología y Geología (CONICET-UNRN), Av. Roca 1242, General Roca, Río Negro, Argentina \\ ${ }^{\mathrm{b}}$ Museo Municipal Argentino Urquiza, Jujuy y Chaco s/n, Rincón de los Sauces, Neuquén, Argentina \\ c Museo Provincial de Ciencias Naturales “Prof. Dr. Juan Olsacher”, Dirección Provincial de Minería, Etcheluz y Ejército Argentino, Zapala, Neuquén, \\ Argentina \\ d Departamento Geología y Petróleo, Facultad de Ingeniería, Universidad Nacional del Comahue, Buenos Aires 1400, Neuquén, Argentina
}

\section{A R T I C L E I N F O}

\section{Article history:}

Received 29 March 2017

Received in revised form

24 July 2017

Accepted in revised form 30 July 2017

Available online 12 August 2017

\section{Keywords}

Ornithischia

Santonian

Patagonian

Biodiversity

\begin{abstract}
A B S T R A C T
In the last decades, the Argentinian ornithopod record has been increased with new and diverse bone remains found along all the Upper Cretaceous. Most of them are very incomplete and represent taxa of different size. As result, the studies about the palaeobiodiversity of the Ornithopoda clade in South America are complex. In this paper, new postcranial remains of an indeterminate medium-sized ornithopod from the Santonian Bajo de la Carpa Formation (Rincón de los Sauces, Neuquén province) are presented. They present diagnostic features of the Ornithopoda clade, and several characters that relate them with other Argentinian ornithopods, especially with the medium-sized members of the Elasmaria clade sensu Calvo et al. (2007) (Macrogryphosaurus and Talenkauen). The postcranial material allows to identificate at least three different ontogenetic stages: adult, subadult more immature and subadult. These bones are the first record of Ornithopoda for the Bajo de la Carpa Formation and one of the very scarce Santonian records of this clade in South America. The diversity of the Late Cretaceous South American ornithopods presents two clear distributions: the Cenomanian-Santonian was characterized by small and medium euiguanodonts and elasmarian; and the Campanian-Maastrichtian by the medium sized elasmarian and large sized hadrosaurids.
\end{abstract}

(C) 2017 Elsevier Ltd. All rights reserved.

\section{Introduction}

The ornithopods are the herbivorous dinosaurs with the greatest taxonomical diversity and time duration from the Mesozoic. Although, their remains are more abundant in the Northern Hemisphere (Horner et al., 2004; Norman et al., 2004; DíazMartinez et al., 2015), in the last decades new and important discoveries have been done in the Southern Hemisphere, mainly in Argentina (i.e., Coria and Cambiaso, 2007; Coria et al., 2007; Ibiricu et al., 2010, 2014; Cruzado-Caballero, 2016; Cruzado-Caballero and Coria, 2016; Cruzado-Caballero et al., 2016a; Cruzado-Caballero and Powell, 2017). Up to date, eight species of ornithopods haven been described: three basal ornithopods (Gasparinisaura cincosaltensis Coria and Salgado 1996a; Notohypsilophodon comodorensis

\footnotetext{
* Corresponding author.

E-mail address: pccaballero@unrn.edu.ar (P. Cruzado-Caballero).
}

Martínez 1998; Anabisetia saldiviai Coria and Calvo 2002), two elasmarians (Talenkauen santacrucensis Novas, Cambiaso and Ambrosio 2004; Macrogryphosaurus gondwanicus Calvo, Porfiri and Novas 2007) and three hadrosaurid (Secernosaurus koerneri Brett-Surman 1979; Lapampasaurus cholinoi Coria, González Riga, and Casadío 2012; Bonapartesaurus rionegrensis CruzadoCaballero and Powell, 2017). In addition, abundant fragmentary remains assigned to high taxonomic levels, such as indeterminate ornithopods, iguanodonts and hadrosaurids have been identified (Cruzado-Caballero, 2015; Cruzado-Caballero et al., 2016a, 2016b).

In this work, we present new postcranial bones of indeterminate ornithopods found in the area of Cerro Overo by the Museo Argentino Urquiza team (Rincón de los Sauces, Neuquén province) during the prospection campaign of 2015-2016 (Fig. 1). Initially, the geological outcrops exposed in this area were assigned to the Anacleto Formation (Campanian) but recent studies in the same stratigraphical levels reassigned them to the Bajo de la Carpa 


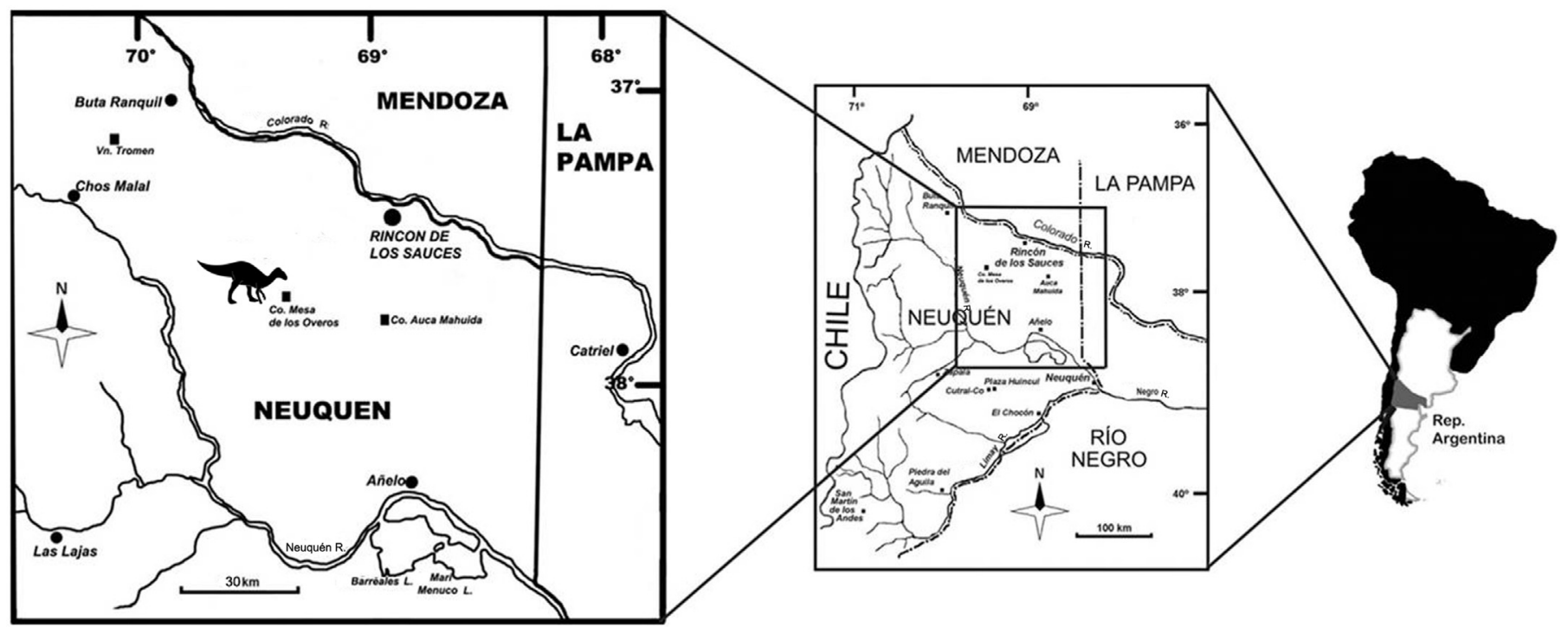

Fig. 1. Map showing the location of the Cerro Overo site (Rincón de los Sauces, Neuquén, Argentina). Abbreviations: Co, cerro; L, Lake; R, river; Vn, volcano.

Formation (Santonian, Garrido, 2010) of the Río Colorado Subgroup, Neuquén Group (Neuquén Basin).

The main goals of the present paper are: to describe the new ornithopod remains; to compare them with other Argentinian ornithopods; and to provide new insights into the palaeobiodiversity and paleobiogeography of the ornithopods in South America.

Institutional Abbreviations-MAU, Museo Argentino Urquiza (Rincón de los Sauces, Neuquén, Argentina).

\section{Geological setting}

During the Late Cretaceous the Neuquén Basin (northern Patagonia and part of Cuyo regions, Argentina) started a foreland stage, give place to a thick succession of continental red beds that includes extensive fluvial deposits and associated aeolian sedimentites. This succession is known lithostratigraphically as Neuquén Group (Cenomanian-lower Campanian), reaching an estimated maximum thickness of $1200 \mathrm{~m}$ (Cazau and Uliana, 1973). From the first geological descriptions of these deposits at the end of the nineteenth century, it was noticed the frequent presence of dinosaur remains, for which reason it was called for a long time as "areniscas con dinosaurios", "formación de dinosaurios", "capas con dinosaurios" or "estratos con dinosaurios" (Valentin, 1897; Roth, 1898; Wichmann, 1916; Windhausen, 1922; Keidel, 1925; among others).

The Bajo de la Carpa Formation integrate the upper part of the Neuquén Group (Río Colorado Subgroup), and offers a wide variety of lithofacies that include a domain of aeolian deposits in the eastern part of the basin, and low-sinuosity to braided fluvial deposits in the center and northern area de the basin (Heredia and Calvo, 1997, 2002; Caldwell and Albino, 2001; Sánchez et al., 2006; Garrido, 2010). According different authors, a Santonian age is inferred for these deposits (Legarreta and Gulisano, 1989; Bonaparte, 1991; Hugo and Leanza, 2001; Garrido, 2010).

Up until five years ago, the paleontological record of the Bajo de la Carpa Formation was mainly restricted to the findings realized in aeolian deposits of the eastern part of the basin, represented by abelisaurids and alvarezsaurids (Bonaparte, 1991; Martinelli and Vera, 2007), fossil birds (Alvarenga and Bonaparte, 1992; Chiappe and Calvo, 1994), abundant remains of the snake Dinilysia patagonica (Smith-Woodward, 1901), and a broad variety of terrestrial crocodiles (Smith-Woodward, 1896; Bonaparte, 1991; Fiorelli and Calvo, 2007; Martinelli and Pais, 2008). In the fluvial facies of this unit, only isolated remains of crocodiles and turtles were reported (Gasparini et al., 1991; Lapparent de Broin and de la Fuente, 2001; Garrido, 2010; Martinelli et al., 2012), as well as sauropod eggshells (Garrido and Calvo, 2004) and remains of the titanosaur Bonitasaurua salgadoi Apesteguía, 2008.

Recent field works developed at the north central area of the basin, close to Rincón de los Sauces city, have allowed stratigraphically relocating to the titanosaurs Rinconsaurus caudamirus Calvo and Riga, 2003, and Overosaurus paradasorum Coria et al., 2013, within the fluvial deposits of the Bajo de la Carpa Formation (Filippi, 2015). Likewise, a new broad fossil vertebrate palaeodiversity for the same deposits was recently cited by Filippi et al. (2015) and Cruzado-Caballero et al. (2016), integrated by fish (Dipnoi) remains, theropod eggs, and a numerous bones of a broad variety of sauropod, theropod and ornithopods dinosaurs.

In the study area, the Bajo de la Carpa Formation exhibit a thickness of $108 \mathrm{~m}$, composed by thick beds of medium to finegrained size sandstones and interbedded red massive mudstones, interpreted as anastomosed fluvial system deposits (Méndez et al., 2015). Ornithopod fossil remains were found disarticulated in two different levels situated in the last $30 \mathrm{~m}$ of this unit, associated to crevasse splay and muddy floodplain deposits. At both levels, the bones were found scattered in a reduced area (less than $36 \mathrm{~m}^{2}$ ).

\section{Systematic palaeontology}

Dinosauria Owen, 1842

Ornithischia Seeley, 1887

Ornithopoda Marsh, 1881

Ornithopoda indet. (Figs. 3-5)

Horizon and locality. Santonian, Bajo de la Carpa Formation, Cerro Overo fossil locality, near Rincón de los Sauces.

Material. MAU-Pv-CO-564 to 565, two fragments of cervical vertebrae; MAU-Pv-CO-569 to 572 and MAU-Pv-CO-574 to 575, five caudal vertebrae centra; MAU-Pv-CO-576, a fragmentary left coracoid; MAU-Pv-CO-577, a fragmentary right ischium; MAU-PvCO-578, a fragmentary left pubis; MAU-Pv-CO-579, a right phalanx II. 


\subsection{Description and comparison}

\subsubsection{Cervical vertebrae}

A partial neural arch of a cervical vertebra (MAU-Pv-CO-565) and an almost complete cervical vertebra slightly eroded (MAU-Pv$\mathrm{CO}-564$, Fig. 2A-C) have been found. MAU-Pv-CO-565 preserves only the left side of the neural arch including part of the transversal process. MAU-Pv-CO-564 exhibits a spool-shaped centrum with a broad ventral keel as in other basal ornithopods (Norman et al., 2004). It has an anteroposterior length/dorsoventral height ratio slightly greater than 2 , as in other Patagonian ornithopods as Gasparinisaura, Anabisetia and Talenkauen (Cambiaso, 2007). MAUPv-CO-564 has an anteroposterior length similar to the seventh and eighth cervical vertebrae of Macrogryphosaurus, this can indicate a similar position in the cervical series to MAU-Pv-CO-564. The articular surfaces are heart-shaped and amphiplatyan as in Macrogryphosaurus and the eighth and ninth cervical vertebrae of other basal ornithopods and differs to the moderate opisthocoelous vertebrae of Talenkauen (Norman et al., 2004; Calvo et al., 2007; Cambiaso, 2007). The hour-glass shaped of the centrum and the presence of a sharp ventral ridge in ventral view are sharing with
Macrogryphosaurus and Talenkauen (Calvo et al., 2007; Cambiaso, 2007). The articular surfaces are sloping anterior and posteriorly, respectively, but not that much as in Macrogryphosaurus (Calvo et al., 2007). The neural arch shows the suture with the centrum indicated an immature stage (Fig. 2A). The neural spine is partially preserved. It is lateromedially narrow and its dorsal border edge is convex in lateral view. The transverse processes are located dorsally to neural arch as in the most posterior cervical vertebra of Talenkauen (Cambiaso, 2007). The right prezygapophysis is broken and the left is almost complete. Both are located anteriorly to the base of the neural spine, the articular surface of the left prezygapophyses has oval-shaped, is flat and is directed upwards and inwards. The postzygapophyses are not preserved.

\subsubsection{Caudal vertebrae}

Five caudal vertebrae centra have been recovered (MAU-Pv-CO569 to 571 and 574 to 575 ; Fig. 2D-O). These centra do not present taphonomic modifications. Only MAU-Pv-CO-569 preserves the base of the neural arch (Fig. $2 \mathrm{~F}-\mathrm{N}$ ). The centra show characters of the basal ornithopods: amphicoelous and hexagonal articular surfaces and bodies progressively lower and slenderer toward the

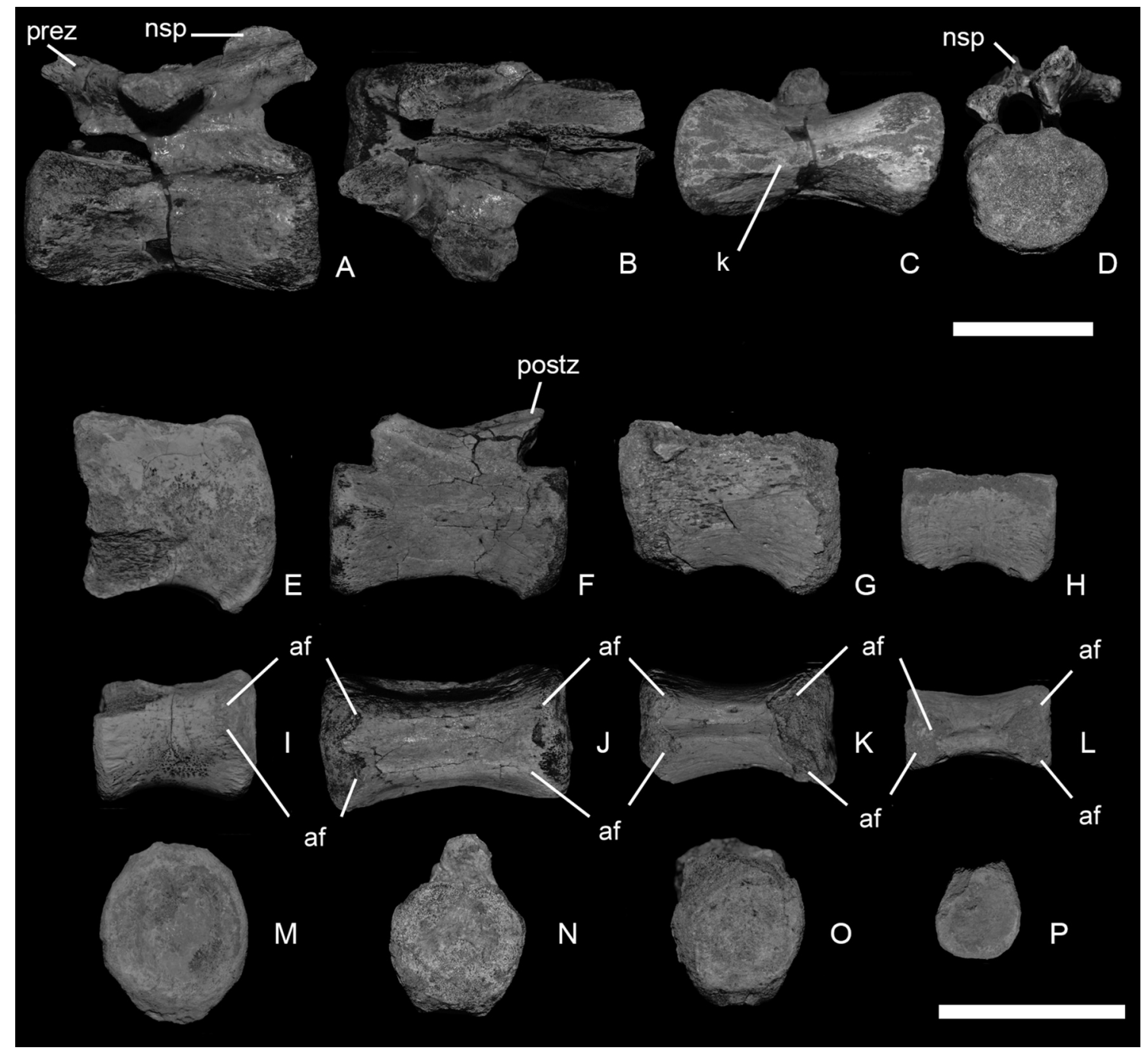

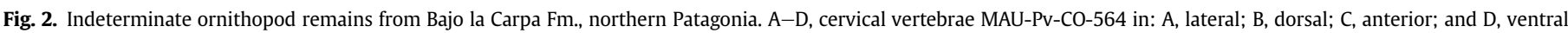

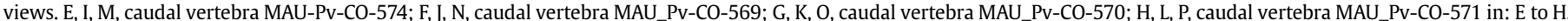

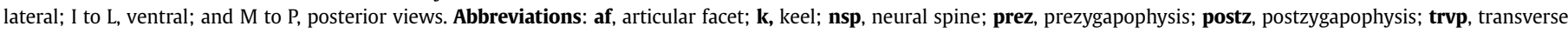
process. Scale bar equals $5 \mathrm{~cm}$. 


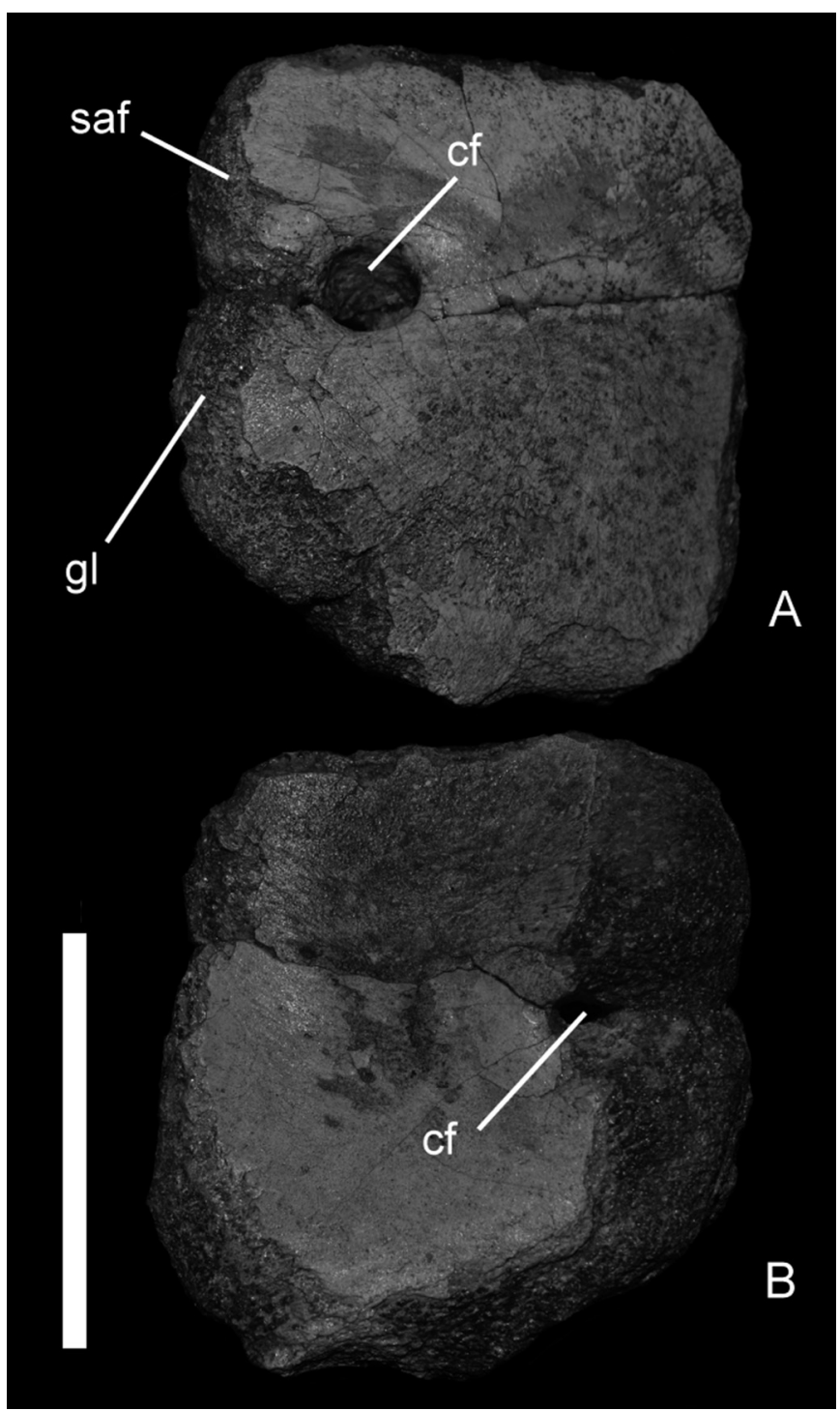

Fig. 3. Coracoid MAU-Pv-CO-576 in: A, lateral; B, medial views. Abbreviations: cf, coracoid foramen; gl, glenoid; s, suture; saf, scapular articular face. Scale bar equals $5 \mathrm{~cm}$.

distal end of the tail (Norman et al., 2004). These centra exhibit different ontogenetic stages. MAU-Pv-CO-570, 571 and 575 show the neurocentral suture unfused, as in immature individuals (Fig. 2G-H, K-L, O-P). MAU-Pv-CO-574 perhaps had the neural arch fused but this zone is broken and eroded (Fig. 2E-M). MAUPv-CO-569 has part of the neural arch fused. The centra of all vertebrae are anteroposteriorly longer than dorsoventrally tall. These have a double rounded border with a furrow between them. MAU-Pv-CO-574 and 575 only have haemal facets in the posterior border, this indicate a possible anterior position in the caudal series. The rest of the centra have haemal facets in both borders indicate more posterior positions in the series. The ventral margin of the centra is concave in lateral view.

\subsubsection{Coracoid}

MAU-Pv-CO-576 corresponds to a left fragment of coracoid with the sternal process broken (Fig. 3A-B). Its proportions are similar to the fragmentary coracoid of Talenkauen (Novas et al., 2004). It is anteroposteriorly width and lateromedially narrow. The lateral side is flat and the medial side is slightly concave. The coracoid foramen is circular-shaped in lateral view and ellipsoidal-shaped in medial view as in Talenkauen (Novas et al., 2004). The foramen does not contact directly with the scapulocoracoid suture but there is an almost close sulcus in lateral (Fig. 3A) and medial side that connects the foramen with the scapulocoracoid suture (Fig. 3B), unlike Talenkauen where the sulcus only observes in the medial side (Cambiaso, 2007). The angle between the articular surfaces is of $135^{\circ}$

\subsubsection{Pubis}

MAU-Pv-CO-578 is a right pubis fragmentary with the prepubic process and the iliac peduncle preserved (Fig. 4A-B). It has a similar size than the same bone corresponding to Macrogryphosaurus (Calvo et al., 2007). The prepubic process is slender, anteroposteriorly elongate, thickness lateromedially and very narrow dorsoventrally like Macrogryphosaurus unlike Talenkauen, which has a narrow lateroventrally prepubic process (Calvo et al., 2007; Cambiaso, 2007). An elongate prepubic process is the general condition for most basal ornithischians, except in basal forms such as Heterodontosaurus (Crompton and Charig, 1962) and Eocursor (Butler, Smith and Norman 2007), where it is short and robust (Norman et al., 2004; Makovicky et al., 2011). This process is anteriorly projected; the dorsal edge is concave and the ventral edge is apparently straight, as in the fragment corresponding of Macrogryphosaurus and unlike Talenkauen which has a convex ventral edge, in lateral view (Calvo et al., 2007; Cambiaso, 2007). Its transversal section in the base of the prepubic process is triangular like Macrogryphosaurus and unlike Talenkauen with an ellipsoidal transversal section (Calvo et al., 2007; Cambiaso, 2007). The iliac peduncle is big, robust and posteriorly directed. Its articular surface is concave, quadrangular and is posteriorly directed as in Anabisetia and Macrogryphosaurus (Calvo et al., 2007; Cambiaso, 2007).

\subsubsection{Ischium}

MAU-Pv-CO-577 is a proximal fragment of a right ischium (Fig. 4C). This fragment preserves the iliac and pubic peduncles. The iliac peduncle has a quadrangular articular surface and is slightly longer than the pubic peduncle, as in other basal ornithopod (Norman et al., 2004). The pubic peduncle is not complete; the preserved part of the articular surface is rectangular. The acetabulum is large, concave and shows a sulcus between both peduncles in medial view.

\subsubsection{Phalanges}

Two pedal phalanges have been found: a proximal phalanx of a left digit IV (MAU-Pv-CO-579) and an ungual phalanx likely belong to digit II or IV (MAU-Pv-CO-580). MAU-Pv-CO-579 has been considered as a proximal phalanx due to its proximal articular facet is concave (see Dieudonné et al., 2016; Fig. 5A-D). It is asymmetric dorsoventrally; typical of digit II and IV phalanges (see Dieudonné et al., 2016). In addition, the proximal articular surface is triangular and projected ventrally as occur in the proximal phalanges of digit IV. The medial condyle is dorsoventrally developed, whereas the lateral condyle is rather distally projected. These features support the identification of this bone as a phalanx of a left digit (sensu Dieudonné et al., 2016). The proximal articular surface is triangular and the distal articular surface is rectangular. It is robust and has a subtriangular mid-shaft cross-section. The distal articular facet presents a midline groove that separates the joint surface in two approximately equal-sized condyles. These features are present in non-hadrosaurid ornithopods and in some theropods (I. D-M. pers. obs.). The insertions of the collateral ligament are marked as a depression in lateral and medial views like the mark of M. extensor in dorsal view. In basal ornithopods (see Zheng et al., 2012) like Talenkauen, Gasparinisaura and Anabisetia the insertions show deep 


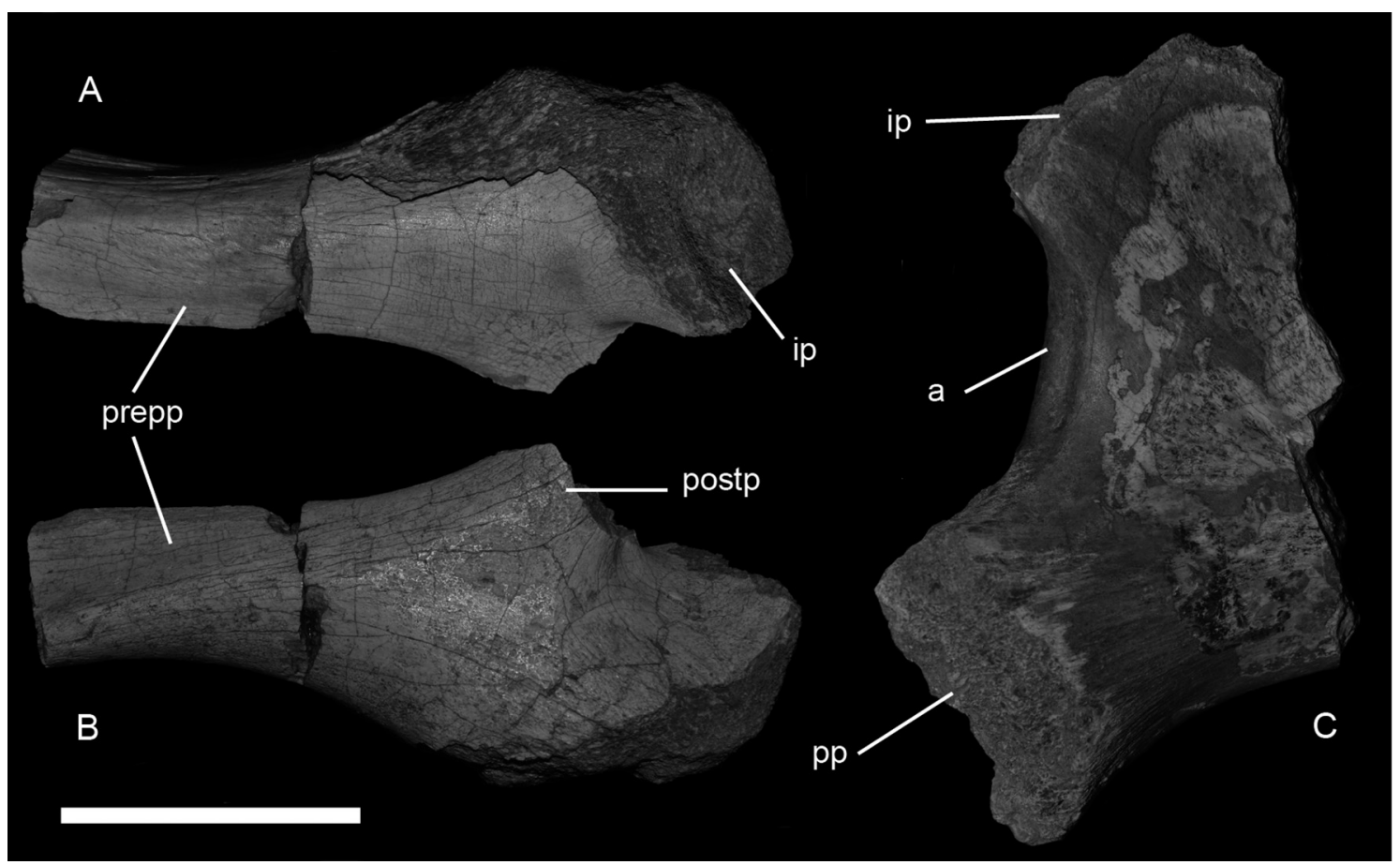

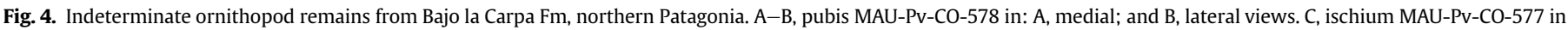
C, medial view. Abbreviations: a, acetabulum; ip, iliac peduncle; pp, pubis peduncle; prepp, prepubic process; postp, postpubic process. Scale bar equals 5 cm.

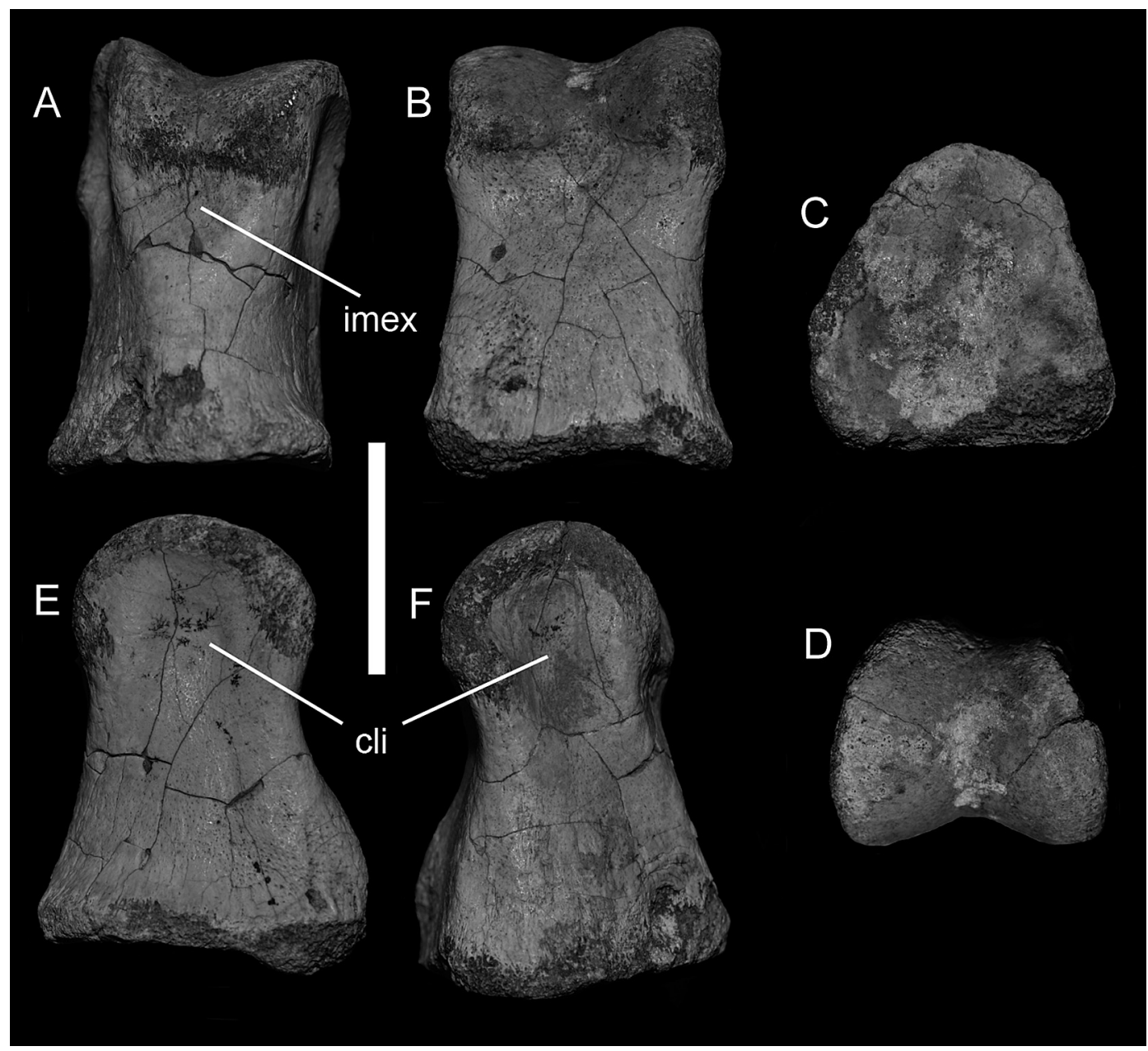

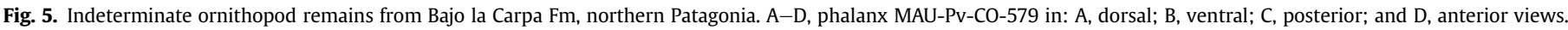
Abbreviations: cli, collateral ligament insertion; imex, insertion M. extensor; vg, vascular groove. Scale bar equals $2 \mathrm{~cm}$. 
pits and the hadrosaurids lack this type of insertion (see DíazMartínez et al., 2012).

\section{Discussion}

The cervical vertebra (MAU-Pv-CO-564) shows a spool-shaped centrum and a broad median ventral keel. Both features are typical of the basal ornithopods (Norman et al., 2004). In the vertebral body, the ratio between anteroposterior length/dorsoventral height is similar to other Argentinian ornithopods (Gasparinisaura, Anabisetia and Talenkauen; Cambiaso, 2007). The anteroposterior length of the vertebral body is similar to the seventh and eighth cervical vertebrae of Macrogryphosaurus (Calvo et al., 2007). The articular surfaces are amphiplatyan as in Macrogryphosaurus and the eighth and ninth cervical vertebrae of basal ornithopods (Norman et al., 2004; Calvo et al., 2007). The ventral ridge is sharp like in Macrogryphosaurus and Talenkauen (Novas et al., 2004; Calvo et al., 2007). The transversal processes are located dorsally to neural arch as in Talenkauen (Novas et al., 2004). Based on all these features, the cervical vertebra is assigned to an indeterminate ornithopod similar to Macrogryphosaurus and Talenkauen.

The Caudal vertebrae (MAU-Pv-CO-569 to 570 and 573 to 575) show typical features of the Ornithopoda clade (spool-shaped centra, amphicoelous and hexagonal articular surfaces; Norman et al., 2004). Due to these remains not sharing specific features, except the size with Macrogryphosaurus and Talenkauen (Novas et al., 2004; Calvo et al., 2007), that permit to refer the specimens to a taxon higher than the Ornithopoda, these remains are assigned to an indeterminate ornithopod.

The coracoid (MAU-Pv-CO-576) apparently has the typical oval shape that presents the majority of ornithopods (Cambiaso, 2007). The foramen is close to the sulcus in medial and lateral side connecting it with the scapulocoracoid suture. In Talenkauen the sulcus is only present in the medial side (Cambiaso, 2007). Therefore, it is assigned to an indeterminate ornithopod.

The pubis (MAU-Pv-CO-578) is similar to the basal ornithopods (slender prepubic process; Norman et al., 2004). The articular face of iliac peduncle is posteriorly directed (Coria and Calvo, 2002. Calvo et al., 2007). MAU-Pv-CO-578 share with Macrogryphosaurus a triangular transversal section (wide dorsal side and a narrow ventral side); different from Talenkauen that has an ellipsoidal transversal section (Calvo et al., 2007; Cambiaso, 2007). The size is approximately equal to the Macrogryphosaurus pubis (Calvo et al., 2007). Thus, this bone is assigned to an indeterminate ornithopod similar to Macrogryphosaurus.

The ischium (MAU-Pv-CO-577) present some features common with other ornithopods, such as the iliac peduncle has a quadrangular articular face and is slightly longer than the pubic peduncle (Norman et al., 2004). Due to this is assigned to an indeterminate ornithopod.

The proximal phalanx IV-1 MAU-PV-CO-579 presents a depression in the collateral ligament insertion and M. extensor insertions. Basal ornithischians and basal ornithopods present both insertions very deep marked (Zheng et al., 2012), as occur in theropod dinosaurs, while hadrosaurid ornithopods have very shallow insertions (Moreno et al., 2007; Díaz-Martínez et al., 2012). Ornithopods of South American as Anabisetia, Gasparinisaura, Notohypsilophodon and Talenkauen present more marked and deeper insertions than MAU-Pv-CO-579. We consider it as indeterminate ornithopod phalanx.

Three different ontogenetic stages have been identified with the described above material allow to discuss the ontogenetic stages (adult, subadult more immature and subadult) of some bones. The caudal vertebra MAU-Pv-CO-569 shows the remains of the neural arch fused to the centrum (adult ontogenetic stage). This is a typical feature of the adult dinosaurs. The cervical vertebra MAU-Pv-CO564 has a visible suture between the neural arch and the centrum (subadults ontogenetic stage). This feature is present in subadult individuals, and is similar in size with those of Macrogryphosaurus and Talenkauen that are considered subadults as well. The neural arches and the centra are completely unfused (a more immature subadult ontogenetic stage) in three caudal vertebrae (MAU-Pv-CO-570, 571 and 575). They represent three more immature subadults.

Taking into account the above descriptions and comparisons, the new material is classified as Ornithopoda indet. Moreover, it presents affinities with the elasmarian Macrogryphosaurus and Talenkauen.

\subsection{Late Cretaceous biodiversity of South American ornithopods}

The Late Cretaceous South American ornithopod record is scarce and its biodiversity is poorly known (see references in DíazMartinez et al., 2015, 2016; Cruzado-Caballero, 2016) when compared with coeval sauropod and theropod dinosaurs. Almost all this record is located in Argentina, with the exception is of an indeterminate ornithopod from Turonian-Santonian of Uruguay (Huene, 1934; M. Soto, pers. comm. in Novas, 2009).

The ichnological record is scarcer than the skeletal one (see Díaz-Martinez et al., 2015, 2016). Few track sites with ornithopod tracks of Cenomanian age are cited from Brazil and Argentina (Calvo, 1991; Carvalho, 2001). In addition, large ornithopod tracks have been cited in the uppermost Cretaceous of Argentina and Peru (Alonso, 1980; Alonso and Marquillas, 1986; Jaillard et al., 1993; Díaz-Martínez et al., 2016). All the putative trackmakers of these tracks are related with large-sized iguanodontian ornithopods (see Díaz-Martinez et al., 2015, 2016). There are no data of Late Cretaceous small ornithopod tracks in South America. The similarities between theropod and basal ornithopod tracks (see Wright, 2004) can cause that ornithopod tracks have been misidentified as theropod ones.

In Argentina, several lithostratigraphic units from Cenomanian to Maastrichtian have yielded ornithopod remains (Fig. 6, Tables 1-3). Although there were found ornithopod bones in all the Upper Cretaceous stages, almost all this record is composed by fragmentary remains without diagnostic characters that allow assigning them to a more specific taxon or studying their phylogenetic relationships (Tables 1-3). Thus, representative biodiversity studies of South American ornithopods are difficult to performance.

In the Cenomania-Turonian, apart from indeterminated ornithopods and iguanodonts (Canudo et al., 2013; Coria and Salgado, 1996a; Coria et al., 2004, 2007; Ibiricu et al., 2010; Table 1), members of small-sized Euiguanodontia and medium-sized Elasmaria have been identified. Notohypsilophodon comodorensis Martínez, 1998 (an elasmarian sensu Boyd, 2015) was found in the Bajo Barreal Formation (middle Cenomanian-Turonian) in Chubut province, Argentina. Finally, in the Turonian Cerro Lisandro Formation (Neuquén province, Argentina), the euiguanodont Anabisetia saldiviai Coria and Calvo, 2002 was described. The taxon "Loncosaurus argentinus" Molnar, 1980 (Mata Amarilla Formation, Cenomanian-Santonian) is considered as nomen vanum (see Coria and Cambiaso, 2007). Out of Argentina there is an indeterminate ornithopod from Turonian-Santonian of Uruguay.

In the Coniacian-Santonian, some fragmentary remains were classified as Ornithopoda indet. (Salgado et al., 2009; CruzadoCaballero et al., 2016; in this work; Table 2) and Iguanodontia indet. (Porfiri and Calvo, 2002; Calvo and Porfiri, 2003; Coria and Cambiaso, 2007). In the middle-upper Coniacian of Sierra Barrosa 


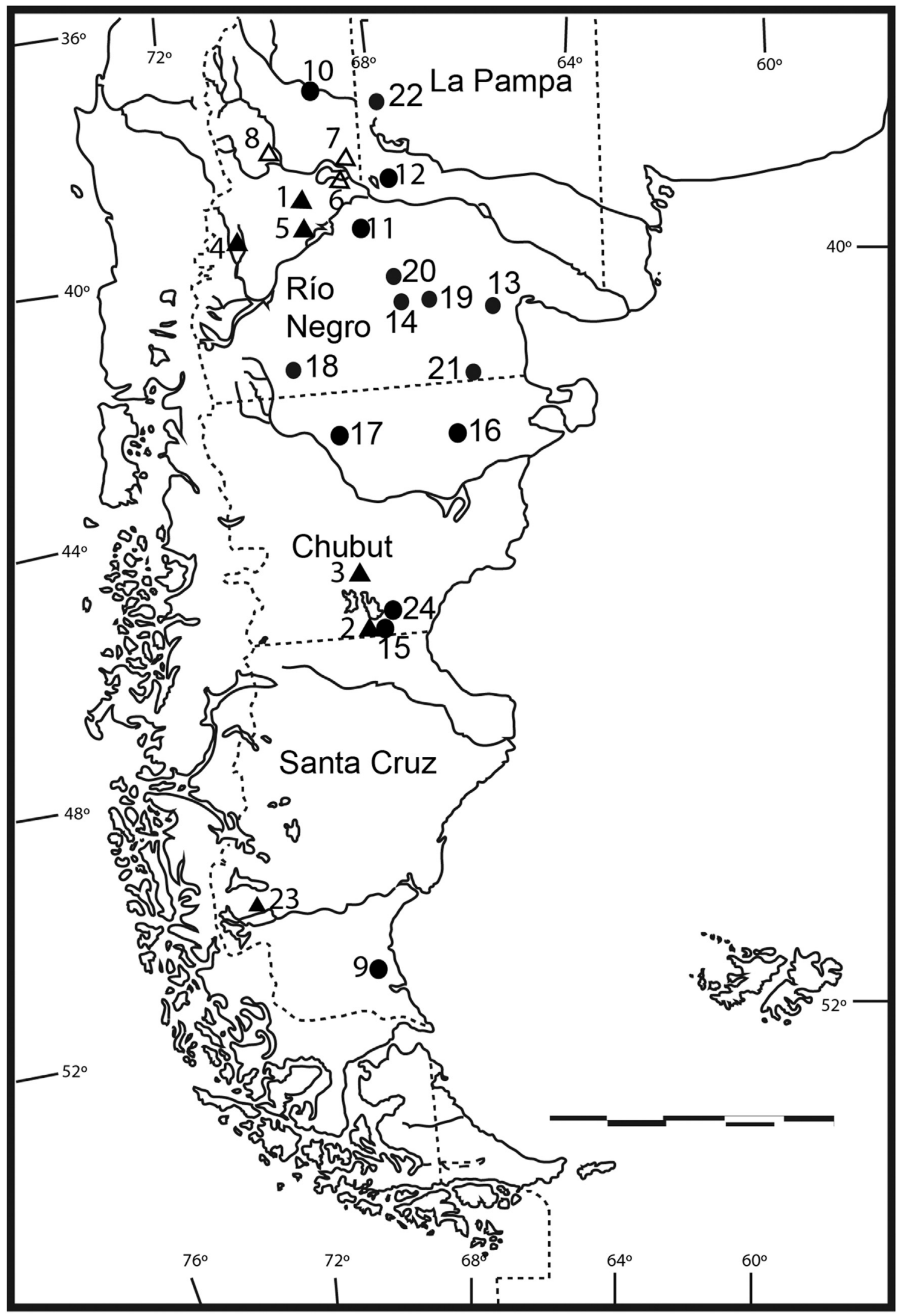

Fig. 6. Distribution map of the ornithopod record in Argentina during Late Cretaceous. Black triangle: ornithopod record during Cenomania-Turonian; white triangle: ornithopod record during Coniacian-Santonian; circle: ornithopod record during Santonian-Maastrichtian. Scale $500 \mathrm{~km}$. 
Table 1

South American ornithopod record during Cenomania-Turonian (Late Cretaceous).

\begin{tabular}{|c|c|c|c|c|c|c|}
\hline Number & Locality & Taxon & Current status & Age & Stratigraphic unit & References \\
\hline 1 & $\begin{array}{l}\text { Plaza Huincul } \\
\text { (Neuquén province) }\end{array}$ & Iguanodontia indet. & Iguanodontia indet. & Cenomanian & $\begin{array}{l}\text { Huincul Fm. (ACG pers. obs.), } \\
\text { Río Limay Subgroup, Neuquén Group }\end{array}$ & $\begin{array}{l}\text { Coria et al. (2004) } \\
\text { Coria et al. (2007) }\end{array}$ \\
\hline 2 & $\begin{array}{l}\text { Southeastern of the } \\
\text { Colhué Huapi lake } \\
\text { (Chubut province) }\end{array}$ & Ornithopoda indet. & Ornithopoda indet. & $\begin{array}{l}\text { Turonian-middle } \\
\text { Cenomanian }\end{array}$ & Bajo Barreal Fm., Upper Member & Ibiricu et al. (2010) \\
\hline 3 & $\begin{array}{l}\text { Neighboring of Buen Pasto } \\
\text { (Chubut province) }\end{array}$ & $\begin{array}{l}\text { Notohypsilophodon } \\
\text { comodorensis }\end{array}$ & $\begin{array}{l}\text { Notohypsilophodon } \\
\text { comodorensis }\end{array}$ & $\begin{array}{l}\text { Turonian-middle } \\
\text { Cenomanian }\end{array}$ & Bajo Barreal Fm., Chubut Group & $\begin{array}{l}\text { Martínez (1998) } \\
\text { Ibiricu et al. (2014) }\end{array}$ \\
\hline 4 & $\begin{array}{l}\text { Agrio del Medio } \\
\text { (Neuquén province) }\end{array}$ & Ornithopoda indet. & Ornithopoda indet. & $\begin{array}{l}\text { Turonian-late } \\
\text { Cenomanian }\end{array}$ & $\begin{array}{l}\text { Huincul Fm., Río Limay subgroup, } \\
\text { Neuquén Group }\end{array}$ & Canudo et al. (2013) \\
\hline 5 & $\begin{array}{l}\text { Cerro Bayo Mesa } \\
\text { (Neuquén province) }\end{array}$ & Anabisetia saldiviai & Anabisetia saldivia & Turonian & $\begin{array}{l}\text { Cerro Lisandro Fm., Río Neuquén } \\
\text { subgroup, Neuquén Group }\end{array}$ & Coria and Calvo (2002) \\
\hline
\end{tabular}

Table 2

South American ornithopod record during Coniacian-Santonian (Late Cretaceous).

\begin{tabular}{|c|c|c|c|c|c|c|}
\hline Number & Locality & Taxon & Current status & Age & Stratigraphic unit & References \\
\hline 6 & $\begin{array}{l}\text { Southwestern coast of Mari } \\
\text { Menuco lake (Neuquén province) }\end{array}$ & $\begin{array}{l}\text { Macrogryphosaurus } \\
\text { gondwanicus }\end{array}$ & $\begin{array}{l}\text { Macrogryphosaurus } \\
\text { gondwanicus }\end{array}$ & $\begin{array}{l}\text { middle/late } \\
\text { Coniacian }\end{array}$ & $\begin{array}{l}\text { Sierra Barrosa Fm., Río Neuquén } \\
\text { subgroup, Neuquén Group }\end{array}$ & Calvo et al. (2007) \\
\hline 7 & $\begin{array}{l}\text { Northern coast of Los Barreales } \\
\text { lake (Neuquén province) }\end{array}$ & Iguanodontia indet. & Iguanodontia indet. & Coniacian & $\begin{array}{l}\text { Portezuelo Fm., Río Neuquén } \\
\text { subgroup, Neuquén Group }\end{array}$ & $\begin{array}{l}\text { Porfiri and Calvo (2002) } \\
\text { Calvo and Porfiri (2003) }\end{array}$ \\
\hline 8 & Bandera Hill (Neuquén province) & Iguanodontia indet. & Iguanodontia indet. & Coniacian & $\begin{array}{l}\text { Portezuelo Fm., Río Neuquén } \\
\text { Subgroup, Neuquén Group }\end{array}$ & Coria and Cambiaso (2007) \\
\hline
\end{tabular}

Table 3

South American ornithopod record during Santonian-Maastrichtian (Late Cretaceous).

\begin{tabular}{|c|c|c|c|c|c|c|}
\hline Number & Locality & Taxon & Current status & Age & Stratigraphic unit & References \\
\hline 9 & $\begin{array}{l}\text { Pair-Aike (Santa Cruz } \\
\text { province) }\end{array}$ & $\begin{array}{l}\text { "Loncosaurus } \\
\text { argentinus" }\end{array}$ & Ornithopoda indet. & $\begin{array}{l}\text { Cenomanian- } \\
\text { Santonian }\end{array}$ & Mata Amarilla Fm. & $\begin{array}{l}\text { Molnar (1980) } \\
\text { Coria and Salgado } \\
\text { (1996a) } \\
\text { Coria and Cambiaso } \\
(2007)\end{array}$ \\
\hline 10 & $\begin{array}{l}\text { Cerro Overo fossil locality, } \\
\text { Rincón de } \\
\text { los Sauces (Neuquén } \\
\text { province) }\end{array}$ & Ornithopoda indet. & Ornithopoda indet. & Santonian & $\begin{array}{l}\text { Bajo de la Carpa } \\
\text { Formation, Río } \\
\text { Colorado subgroup, } \\
\text { Neuquén Group }\end{array}$ & This paper \\
\hline 10 & $\begin{array}{l}\text { Puesto Hernández quarry } \\
\text { (Neuquén province) }\end{array}$ & Ornithopoda indet. & Ornithopoda indet. & $\begin{array}{l}\text { Late Coniacian-late } \\
\text { Santonian }\end{array}$ & $\begin{array}{l}\text { Plottier Fm., Río } \\
\text { Neuquén subgroup, } \\
\text { Neuquén Group }\end{array}$ & $\begin{array}{l}\text { Cruzado-Caballero et al. } \\
\text { (2016) }\end{array}$ \\
\hline 11 & $\begin{array}{l}\text { El Anfiteatro (Río Negro } \\
\text { province) }\end{array}$ & Ornithopoda indet. & Ornithopoda indet. & $\begin{array}{l}\text { late Coniacian-late } \\
\text { Santonian }\end{array}$ & $\begin{array}{l}\text { Plottier Fm., Río } \\
\text { Neuquén subgroup, } \\
\text { Neuquén Group }\end{array}$ & Salgado et al. (2009) \\
\hline & $\begin{array}{l}\text { Guichón (Paysandù } \\
\text { Departament) }\end{array}$ & Ornithopoda indet. & Ornithopoda indet. & Turonian-Santonian & Mercedes Fm. & $\begin{array}{l}\text { Huene, 1934; M. Soto, } \\
\text { pers. comm. in Novas } \\
\text { (2009) }\end{array}$ \\
\hline 12 & $\begin{array}{l}\text { Cinco saltos (Río Negro } \\
\text { province) }\end{array}$ & $\begin{array}{l}\text { Gasparinisaura } \\
\text { cincosaltensis }\end{array}$ & $\begin{array}{l}\text { Gasparinisaura } \\
\text { cincosaltensis }\end{array}$ & $\begin{array}{l}\text { Santonian early- } \\
\text { Campanian }\end{array}$ & $\begin{array}{l}\text { Anacleto Fm., Río } \\
\text { Colorado subgroup, } \\
\text { Neuquén Group }\end{array}$ & $\begin{array}{l}\text { Coria and Salgado } \\
\text { (1996b) } \\
\text { Salgado et al. (1997) } \\
\text { Coria (1999) } \\
\text { Dingus et al. (2000) } \\
\text { Coria and Cambiaso } \\
\text { (2007) }\end{array}$ \\
\hline 13 & $\begin{array}{l}\text { Tripailao, Valcheta (Río } \\
\text { Negro province) }\end{array}$ & Hadrosauridae indet. & Hadrosauridae indet. & $\begin{array}{l}\text { Santonian?- } \\
\text { Campanian? }\end{array}$ & Río Colorado subgroup? & \\
\hline 14 & $\begin{array}{l}\text { Cerro Mesa, South of Villa } \\
\text { Regina (Río Negro } \\
\text { province) }\end{array}$ & Hadrosauridae indet. & Hadrosauridae indet. & Late Campanian & $\begin{array}{l}\text { Allen Fm., Malargüe } \\
\text { Group }\end{array}$ & $\begin{array}{l}\text { Corsolini (2014) } \\
\text { Coria }(2016)\end{array}$ \\
\hline 15 & $\begin{array}{l}\text { South-east of Lake Colhué } \\
\text { Huapi } \\
\text { (Chubut province) }\end{array}$ & Hadrosauridae indet. & Hadrosauridae indet. & $\begin{array}{l}\text { Campanian- } \\
\text { Maastrichtian? }\end{array}$ & $\begin{array}{l}\text { Bajo Barreal Fm., Upper } \\
\text { Member }\end{array}$ & Luna et al. (2003) \\
\hline 16 & $\begin{array}{l}\text { La colonia (Chubut } \\
\text { province) }\end{array}$ & Hadrosauridae indet. & Hadrosauridae indet. & $\begin{array}{l}\text { Campanian- } \\
\text { Maastrichtian }\end{array}$ & La Colonia Fm. & $\begin{array}{l}\text { Hill et al. (2002) } \\
\text { Gasparini et al. (2015) }\end{array}$ \\
\hline 17 & $\begin{array}{l}\text { Between Paso del Sapo and } \\
\text { Cerro } \\
\text { Cóndor (Chubut province) }\end{array}$ & Hadrosauridae indet. & Hadrosauridae indet. & $\begin{array}{l}\text { Campanian- } \\
\text { Maastrichtian }\end{array}$ & Paso del Sapo Fm. & $\begin{array}{l}\text { Apesteguía and } \\
\text { Cambiaso (1999) } \\
\text { Apesteguía et al. (2012) }\end{array}$ \\
\hline 18 & $\begin{array}{l}\text { Cona Niyeu, } 9 \text { de Julio } \\
\text { Departament } \\
\text { (Río Negro province) }\end{array}$ & Hadrosauridae indet. & Hadrosauridae indet. & $\begin{array}{l}\text { Late Campanian-early } \\
\text { Maastrichtian }\end{array}$ & Los Alamitos Fm. & $\begin{array}{l}\text { Cruzado-Caballero } \\
\text { (2015) }\end{array}$ \\
\hline 18 & $\begin{array}{l}\text { Bajo Colorado, Ingeniero } \\
\text { Jacobacci, } 5 \text { de }\end{array}$ & Hadrosauridae indet. & Hadrosauridae indet. & $\begin{array}{l}\text { Campanian-middle } \\
\text { Maastrichtian }\end{array}$ & $\begin{array}{l}\text { Angostura Colorada/ } \\
\text { Coli Toro Fm. }\end{array}$ & $\begin{array}{l}\text { Cruzado-Caballero } \\
\text { (2015) }\end{array}$ \\
\hline
\end{tabular}


Table 3 (continued)

\begin{tabular}{|c|c|c|c|c|c|c|}
\hline Number & Locality & Taxon & Current status & Age & Stratigraphic unit & References \\
\hline & $\begin{array}{l}\text { Mayo Departament (Río } \\
\text { Negro province) }\end{array}$ & & & & & \\
\hline 18 & $\begin{array}{l}\text { Cerro Mesa, Ingeniero } \\
\text { Jacobacci, } 5 \text { de } \\
\text { Mayo Departament (Río } \\
\text { Negro province) }\end{array}$ & Hadrosauridae indet. & Hadrosauridae indet. & $\begin{array}{l}\text { Campanian-early/ } \\
\text { middle } \\
\text { Maastrichtian }\end{array}$ & $\begin{array}{l}\text { Angostura Colorada/ } \\
\text { Coli Toro Fm. }\end{array}$ & Casamiquela (1964) \\
\hline 13 & $\begin{array}{l}\text { Bajo Santa Rosa, Valcheta } \\
\text { (Río Negro province) }\end{array}$ & Hadrosauridae indet. & Hadrosauridae indet. & $\begin{array}{l}\text { Late Campanian?-early } \\
\text { Maastrichtian? }\end{array}$ & Los Alamitos Fm.? & \\
\hline 19 & $\begin{array}{l}\text { Lamarque (Río Negro } \\
\text { province) }\end{array}$ & Hadrosauridae indet. & Hadrosauridae indet. & $\begin{array}{l}\text { Late Campanian-early } \\
\text { Maastrichtian }\end{array}$ & Los Alamitos Fm. & $\begin{array}{l}\text { Martinelli and Forasiepi } \\
\text { (2004) }\end{array}$ \\
\hline 20 & $\begin{array}{l}\text { Salitral Moreno site, } \\
\text { General Roca } \\
\text { (Río Negro province) }\end{array}$ & $\begin{array}{l}\text { Willinakaqe } \\
\text { salitranensis }\end{array}$ & Hadrosauridae indet. & $\begin{array}{l}\text { Late Campanian-early } \\
\text { Maastrichtian }\end{array}$ & $\begin{array}{l}\text { Allen Fm., Malargüe } \\
\text { Group }\end{array}$ & $\begin{array}{l}\text { Juárez Valieri et al. } \\
\text { (2010) } \\
\text { Cruzado-Caballero and } \\
\text { Coria (2016) }\end{array}$ \\
\hline 20 & $\begin{array}{l}\text { Salitral Moreno site, } \\
\text { General Roca } \\
\text { (Río Negro province) }\end{array}$ & $\begin{array}{l}\text { Willinakaqe } \\
\text { salitranensis }\end{array}$ & $\begin{array}{l}\text { Bonapartesaurus } \\
\text { rionegrensis }\end{array}$ & $\begin{array}{l}\text { Late Campanian-early } \\
\text { Maastrichtian }\end{array}$ & $\begin{array}{l}\text { Allen Fm., Malargüe } \\
\text { Group }\end{array}$ & $\begin{array}{l}\text { Juárez Valieri et al. } \\
\text { (2010) } \\
\text { Cruzado-Caballero and } \\
\text { Powell (2017) }\end{array}$ \\
\hline 21 & $\begin{array}{l}\text { Arroyo Verde región Puelén } \\
\text { Departament } \\
\text { (Río Negro province) }\end{array}$ & Kritosaurus australis & Secernosaurus koerneri & $\begin{array}{l}\text { Late Campanian-early } \\
\text { Maastrichtian }\end{array}$ & Los Alamitos Fm. & $\begin{array}{l}\text { Bonaparte et al. (1984) } \\
\text { Wagner (2001) } \\
\text { Prieto-Marquez and } \\
\text { Salinas (2010) }\end{array}$ \\
\hline 22 & $\begin{array}{l}\text { Islas Malvinas site (La } \\
\text { Pampa province) }\end{array}$ & $\begin{array}{l}\text { Willinakaqe } \\
\text { salitranensis }\end{array}$ & Lapampasaurus cholinoi & $\begin{array}{l}\text { Late Campanian-early } \\
\text { Maastrichtian }\end{array}$ & $\begin{array}{l}\text { Allen Fm., Malargüe } \\
\text { Group }\end{array}$ & $\begin{array}{l}\text { González Riga and } \\
\text { Casadío (2000) } \\
\text { Juárez Valieri et al. } \\
\text { (2010) } \\
\text { Coria et al. (2012) }\end{array}$ \\
\hline 23 & $\begin{array}{l}\text { Los Hornos Hill, Argentino } \\
\text { lake } \\
\text { (Santa Cruz province) }\end{array}$ & $\begin{array}{l}\text { Talenkauen } \\
\text { santacrucensis }\end{array}$ & $\begin{array}{l}\text { Talenkauen } \\
\text { santacrucensis }\end{array}$ & Maastrichtian & Pari Aike Fm. & Novas et al. (2004) \\
\hline 24 & $\begin{array}{l}\text { Chico River, east of Lake } \\
\text { Colhué } \\
\text { Huapi (Chubut province) }\end{array}$ & Secernosaurus koerneri & Secernosaurus koerneri & Maastrichtian & $\begin{array}{l}\text { Bajo Barreal Fm., } \\
\text { Chubut Group }\end{array}$ & $\begin{array}{l}\text { Brett-Surman (1979) } \\
\text { Bonaparte and Powell } \\
(1980)\end{array}$ \\
\hline
\end{tabular}

Formation (Neuquén province, Argentina) the bones of Macrogryphosaurus gondwanicus Calvo et al., 2007, a medium-sized elasmarian ornithopod, were identified. In addition, as it is suggested above, the herein studied remains that belong to medium sized indeterminate ornithopods present affinities with the Elasmaria clade, being the first ornithopod record of the Santonian Bajo de la Carpa Formation. On the other hand, in the Santonian-lower Campanian rocks of Anacleto Formation (Río Negro province, Argentina) some almost complete skeletons of a small sized iguanodont, Gasparinisaura cincosaltensis Coria and Salgado, 1996, were found (Coria and Salgado, 1996b; Salgado et al., 1997; Coria, 1999; Dingus et al., 2000; Coria and Cambiaso, 2007; Salgado et al., 2009).

Finally, the Santonian-Maastrichtian ornithopod record is composed mainly by large sized hadrosaurids (Coria and Cambiaso, 2007; Table 3). Almost all this record is fragmentary and it is considered as Hadrosauridae indet. (Casamiquela, 1964; Coria and Cambiaso, 2007; Cruzado-Caballero, 2015; Coria, 2016; CruzadoCaballero and Coria, 2016), but three hadrosaurids were described: Secernosaurus koerneri Brett-Surman 1979 in the Maastrichtian Bajo Barreal Formation (Chubut province) and upper Campanian-lower Maastrichtian Los Alamitos Formation (Río Negro Formation); Lapampasaurus cholinoi Coria, González Riga, and Casadío 2012 in the upper Campanian-lower Maastrichtian Allen Formation (La Pampa province); and Bonapartesaurus rionegrensis Cruzado-Caballero and Powell, 2017 in the upper Campanian-lower Maastrichtian Allen Formation (Río Negro province). The unique non-hadrosaurid ornithopod record found in Maastrichtian rocks is the medium sized elasmarian Talenkauen santacrucensis Novas et al., 2004 (Pari Aike Formation, Santa Cruz province).

Based on the above data, it would be presumed that: a) during the Cenomanian-Santonian the ornithopod diversity was characterized by small and medium sized euiguanodonts and elasmarian; b) in the Campanian-Maastrichtian there were medium sized elasmarian and large sized hadrosaurids, being the later the most abundant taking into account the number of findings. The Campanian-Maastrichtian of the Antarctica presents the same ornithopod diversity (see Rozadilla et al., 2016).

As well as the Elasmaria clade is present in South America (at least in Argentina) in all the Upper Cretaceous, the Euiguanodontia and Hadrosauridae have a particular temporal distribution. Euiguanodonts are located between Cenomanian and Santonian. The lack of this record in the Campanian-Maastrichtian could be due to a taphonomical bias or an ecologic replacement. Towards this second option, in the Campanian-Maastrichtian the establishment of land connections between Gondwana and Laurasia produced the presence of immigrant taxa like the hadrosaurids (see Leanza et al. 2004) that could compete for the ecologic niches. However, taking into account the difference of size between euiguanodonts and hadrosaurids is improbable an ecologic replacement, unless a global or regional change could modify the ecosystems (e.g., the late Campanian Atlantic flooding episode over Patagonia, see Legarreta et al., 1989; Malumian and Carames, 1995; Parras et al., 1998).

\section{Conclusions}

The material studied herein present diagnostic features of the Ornithopoda clade, and several characters that suggest affinities with other Argentinian ornithopods, especially with the mediumsized members of the Elasmaria clade (Macrogryphosaurus and Talenkauen). The material belongs to at least three different ontogenetic stages (an adult, a more immature subadult and a subadult). The bones found in the Cerro Overo site are the first ornithopod remains of this clade from Bajo de la Carpa of Santonian in age (Neuquén Group, Neuquén province, Argentina). Based on the Late Cretaceous ornithopod record in South America (almost all found in 
Argentina), the diversity presents a temporal distribution. The medium sized elasmarian are present in all the Upper Cretaceous, from Cenomanian to Maastrichtian. On the other hand, the small sized euiguanodonts were identified in Cenomanian-Santonian rocks, and disappear just when the large hadrosaurids arrived from the Northern hemispheres during the Campanian-Maastrichtian.

\section{Acknowledgements}

Financial support has been provided by the municipality of Rincón de los Sauces, Neuquén Province, Argentina (LSF), Agencia Nacional de Promoción Científica y Técnica (PICT 2011-1989; AHM) and the Spanish Ministerio de Ciencia e Innovación (CGL201453548-P; PCC). The excavations and restoration of the fossils have been supported by the municipality of Rincón de los Sauces (Neuquén, Argentina). We acknowledge Dr. José Manuel Gasca (Museo Provincial de Ciencias Naturales "Prof. Dr. Juan Olsacher", Zapala, Argentina) and Dr. Julio Company (Departamento de Ingeniería del Terreno, Universidad Politécnica de Valencia, Spain) for their comments on the manuscript. We also thank the labour of Eduardo Koutsoukos, Editor in Chief.

\section{References}

Alonso, R.N., 1980. Icnitas de dinosaurios (Ornithopoda, Hadrosauridae) en el Cretácico Superior de norte de Argentina. Acta Geologica Lilloana 15, 55-63.

Alonso, R.N., Marquillas, R.A., 1986. Nueva localidad con huellas de dinosaurios y primer hallazgo de huellas de aves en la Formación Yacoraite (Maastrichtiense) del Norte Argentino. Actas $4^{\circ}$ Congreso Argentino de Paleontología y Bioestratigrafía, Mendoza 2, 33-41.

Alvarenga, H., Bonaparte, J.F., 1992. A new flightless land-bird from the Cretaceous of Patagonia. In: Campbell, K.E. (Ed.), Papers in Avian Paleontology. Natural History Museum of Los Angeles County, Science Series 36, pp. 51-64.

Apesteguía, S., Cambiaso, A., 1999. Hallazgo de hadrosaurios en la Formación Paso del Sapo (Campaniano-Maastrichtiano, Chubut): otra localidad del "Senoniano lacustre". Ameghiniana, Suplemento Resúmenes, 36, 4 5R.

Apesteguía, S., Cambiaso, A., Agnolin, F., 2012. Vertebrados de la Formación Paso de Sapo (Campaniano/Maastrichtiano), provincia de Chubut, Argentina. Ameghiniana 49 (3), 395-400.

Bonaparte, J.F., 1991. Los vertebrados fósiles de la Formación Río Colorado, de la ciudad de Neuquén y cercanías, Cretácico Superior, Argentina. Revista de Museo Argentino de Ciencias Naturales Bernardino Rivadavia 5, 16-124.

Bonaparte, J.F., Powell, J.E., 1980. A continental assemblage of tetrapods from the upper Cretaceous beds of El Brete, North-western Argentina (Sauropoda-Coelurosauria-Carnosauria-Aves). Mémoires de le Société Géologique de France N. S. $59,18-28$.

Bonaparte, J.F., Franchi, M.R., Powell, J.E., Sepulveda, E.G., 1984. La Formación Alamitos (Campaniano-Maastrichtiano) del sudeste del Río Negro, con descripción de Kritosaurus australis n. sp. (Hadrosauridae). Significado paleogeográfico de los vertebrados. Revista de la Asociación Geológica Argentina 39, 284-299.

Brett-Surman, M.K., 1979. Phylogeny and Paleobiogeography of Hadrosaurian Dinosaurs. Nature 277 (15), 560-562.

Butler, R.J., Smith, R.M.H., Norman, D.B., 2007. A primitive ornithischian dinosaur from the Late Triassic of South Africa, and the early evolution and diversification or Ornithischia. Proceedings of the Royal Society, B 274, 2041-2046.

Caldwell, M.W., Albino, A.M., 2001. Palaeoenvironment and palaeocology of three Cretaceous snakes: Pachyophis, Pachyrhachis, and Dinilysia. In: Vizcaino, S.F. Janis, R.A. Farifla y C. (Eds.), Biomechanics and Palaeobiology of Vertebrates. Acta Palaeontologica Polonica, 46, pp. 203-218.

Calvo, J.O. 1991. Huellas de dinosaurios en la Formación Rio Limay (Albiano-Cenomaniano?), Picun Leufu, Provincia de Neuquén, República Argentina. (Ornithischia-Saurischia: Sauropoda-Theropoda). Ameghiniana 28 (3-4), 241-258.

Calvo, J.O., González Riga, B.J., 2003. Rinconsaurus caudamirus gen. et sp nov., a new titanosaurid (Dinosauria, Sauropoda) from the Late Cretaceous of Patagonia, Argentina. Revista Geológica de Chile 30, 333-353.

Calvo, J.O., Porfiri, J.D., 2003. More evidence of basal Iguanodontians from Barreales Lake (Upper Turonian-Lower Coniacian), Neuquén, Patagonia, Argentina. Ameghiniana, Suplemento Resúmenes 40, 53R.

Calvo, J.O., Porfiri, J.D., Novas, F.E., 2007. Discovery of a new ornithopod dinosaur from the Portezuelo Formation (Upper Cretaceous), Neuquén, Patagonia, Argentina. Arquivos do Museu Nacional, Rio de Janeiro 65, 471-483.

Cambiaso, A.V., 2007. Los ornitópodos e iguanodontes basales (Dinosauria, Ornithischia) del Cretácico de Argentina y Antártida. PhD Thesis. Universidad de Buenos Aires Facultad de Ciencias Exactas y Naturales, 412 pp.

Canudo, J.I., Salgado, L., Garrido, A., Carballido, J., 2013. Primera evidencia de dinosaurios ornitópodos en la base de la Formación Huincul (Cenomaniense Superior-Turoniense, Cuenca Neuquina, Argentina). Geogaceta 53, 9-12.
Carvalho, I.S., 2001. Pegadas de dinossauros em depósitos estuarinos (Cenomaniano) da Bacia de São Luís (MA), Brasil. In: Rossetti, D.F., Góes, A.M., Truckenbrodt, W. (Eds.), O Cretáceo na Bacia de São Luís e Grajaú. Coleção Friedrich Katzer, Museu Paraense Emílio Goeldi, Belém, pp. 245-264.

Casamiquela, R.M., 1964. Sobre un dinosaurio hadrosáurido de la Argentina. Ameghiniana 3, 285-308.

Cazau, L.B., Uliana, M.A., 1973. El Cretácico superior continental de la Cuenca Neuquina. $5^{\circ}$ Congreso Geológico Argentino. Actas 3, 131-163.

Chiappe, L.M., Calvo, J.O., 1994. Neuquenornis volans, a new Late Cretaceous bird (Enantiornithes: Avisauridae) from Patagonia, Argentina. Journal of Vertebrate Paleontology 14, 230-246.

Coria, R.A., 1999. Ornithopod dinosaurs from the Neuquen Group, Patagonia, Argentina; phylogeny and biostratigraphy. In: Tomida, Y., Rich, T.H., VickersRich, P. (Eds.), Proceedings of the Second Gondwanan Dinosaur Symposium. National Science Museum Monographs, 15, pp. 47-60.

Coria, RA 2016. An overview of the ornithischian dinosaurs from Argentina In: Agnolin, F.L., Lio, G.L., Brissón Egli, F., Chimento, N.R., Novas, F.E. (Eds.), Historia evolutiva y paleobioeográfica de los vertebrados de América del Sur. Contribuciones del MACN, Buenos Aires, Argentina, pp. 109-128.

Coria, R.A., Calvo, J.O., 2002. A new iguanodontian ornithopod from Neuquén Basin, Patagonia, Argentina. Journal of Vertebrate Paleontology 22, 503-509.

Coria, R.A., Cambiaso, A.V., 2007. Ornithischia. In: Gasparini, Z., Salgado, L., Coria, R.A. (Eds.), Patagonian Mesozoic Reptiles. Indiana University Press, pp. 167-187.

Coria, R.A., Salgado, L., 1996a. A basal iguanodontian (Ornithischia: Ornithopoda) from the Late Cretaceous of South America. Journal of Vertebrate Paleontology $16,445-457$.

Coria, R.A., Salgado, L., 1996b. "Loncosaurus argentinus” Ameghino, 1899 (Ornithischia, Ornithopoda); a revised description with comments on its phylogenetic relationships. Ameghiniana 3 (4), 373-376.

Coria, R.A., Salgado, L., Currie, P.J., Paulina Carabajal, A., Arcucci, A.B., 2004. Nuevos registros de iguanodontes basales en el Cretácico de norpatagonia. Ameghiniana, Suplemento Resúmenes 41, 42R.

Coria, R.A., Cambiaso, A.V., Salgado, L., 2007. New records of basal ornithopod dinosaurs in the Cretaceous of North Patagonia. Ameghiniana 44 (2), 473-477.

Coria, R.A., González Riga, B., Casadío, S., 2012. Un nuevo hadrosáurido (Dinosauria, Ornithopoda) de la Formación Allen, provincia de la Pampa, Argentina. Ameghiniana 49 (4), 552-572.

Coria, R.A., Filippi, L.S., Chiappe, L.M., García, R., Arcucci, A.B., 2013. Overosaurus paradasorum gen. et sp. nov., a new sauropod dinosaur (Titanosauria: Lithostrotia) from the Late Cretaceous of Neuquén, Patagonia, Argentina. Zootaxa 3683 (4), 357-376.

Corsolini, J., 2014. Osteología craneana y posible ubicación sistemática de un nuevo ejemplar de Hadrosauridae (Dinosauria, Ornithopoda) del Cretácico Superior de la prov. de Río Negro, Argentina. Tesis de Licenciatura, 92 pp.

Crompton, A.W., Charig, A.J., 1962. A new ornithischian from the Upper Triassic of South Africa. Nature 196, 1074-1077.

Cruzado-Caballero, P., 2015. Nuevos restos de dinosaurios hadrosáuridos del Valle de Huahuel Niyeo (Río Negro, Argentina). Ameghiniana 52 (1) Abstracts, Suplemento $6-7$.

Cruzado-Caballero, P., 2016. Ornithopod dinosaurs from Argentina, the forgotten clade. In: Torcida Fernández-Baldor, F., Canudo, J.I., Huerta, P., Pereda, X. (Eds.), Abstract Book, VII International Symposium about Dinosaurs Palaeontology and their Environment, Salas de los Infantes, Burgos, Spain, September 8-10th, pp. $49-52$.

Cruzado-Caballero, P., Coria, R., 2016. Revisiting the hadrosaurid (Dinosauria: Ornithopoda) diversity of the Allen Formation: a re-evaluation of Willinakaqe salitralensis from Salitral Moreno, Río Negro Province, Argentina. Ameghiniana 53 (2), 231-237.

Cruzado-Caballero, P., Powell, J., 2017. Bonapartesaurus rionegrensis, a new hadrosaurine dinosaur from South America: implications for phylogenetic and biogeographic relations with North America. Journal of Vertebrate Paleontology 37 (2), e1289381.

Cruzado-Caballero, P., Filippi, L.S., Méndez, A.H., Díaz-Martínez, I., 2016a. Primeros restos de ornitópodos en la Formación bajo de la Carpa en Rincón de los Sauces (Cretácico Superior). Ameghiniana, 53 (6) Abstrats, Suplemento 13.

Cruzado-Caballero, P., Filippi, L.S., Méndez, A.H., Garrido, A.C., Juárez Valieri, R.D., 2016b. New record of an ornithopod from the Plottier Formation (Upper Cretaceous), Patagonia, Argentina. Annales de Paleontologie 102, 145-150.

Cruzado-Caballero, P., Méndez, A.H., Filippi, L.S., Juárez Valieri, R.D., Garrido, A.C., 2016. Palaeobiodiversity of the Bajo de la Carpa Formation (Santonian, Upper Cretaceous) in the Cerro Overo-La Invernada area, northern Patagonia, Argentina. VII Jornadas internacionales sobre paleontología de dinosaurios y su entorno, Salas de los Infantes (Burgos, España) 53-55.

Díaz-Martínez, I., Lecuona, A., Pérez-Lorente, F., Pereda-Suberbiola, X., Ignacio, J., 2012. Estudio miológico del acropodio de dinosaurios ornitópodos. Abstract book X EJIP. Sot de Chera 68-70.

Díaz-Martinez, I., Pereda-Suberbiola, X., Perez-Lorente, F., Canudo, J.I., 2015. Ichnotaxonomic review of large ornithopod dinosaur tracks: temporal and geographic implications. PLoS One 10 (2), e0115477.

Díaz-Martínez, I., de Valais, S., Cónsole-Gonella, C., 2016. First evidence of Hadrosauropodus in Gondwana (Yacoraite Formation, Maastrichtian-Danian), Northwestern Argentina. Journal of African Earth Sciences 122, 79-87. http:// dx.doi.org/10.1016/j.jafrearsci.2016.02.012. 
Dieudonné, P.-E., Tortosa, T., Torcida Fernández-Baldor, F., Canudo, J.I., DíazMartínez, I., 2016. An unexpected early rhabdodontid from Europe (Lower Cretaceous of Salas de los Infantes, Burgos Province, Spain) and a reexamination of basal iguanodontian relationships. PLoS One 11 (6), e0156251. http://dx.doi.org/10.1371/journal.pone.0156251.

Dingus, L., Clarke, J., Scott, G.R., Swisher, C.C., Chiappe, L.M., Coria, R.A., 2000. Stratigraphy and Magnetostratigraphic/Faunal Constraints for the Age of Sauropod Embryo-Bearing Rocks in the Neuquén Group (Late Cretaceous, Neuquén Province, Argentina). American Museum Novitates 3290, 1-11.

Filippi, L., 2015. Los dinosaurios sauropoda del Cretácico Superior del norte de la Cuenca Neuquina, Patagonia, Argentina. Boletín del Instituto de Fisiografía y Geología 58, 19-28.

Filippi, L., Martinelli, A.G., Garrido, A.C., 2015. Una nueva asociación de dientes de vertebrados para la Formación Bajo de la Carpa (Santoniense, Cretácico Superior) en Rincón de los Sauces, Neuquén, Argentina. Spanish Journal of Palaeontology 30 (2), 223-238.

Fiorelli, L., Calvo, J.O., 2007. The first “Protosuchian” (Archosauria: Crocodyliformes) from the Cretaceous (Santonian) of Gondwana. Arquivos do Museu Nacional 65 (4), 417-459.

Garrido, A.C., 2010. Estratigrafía del Grupo Neuquén, Cretácico Superior de la Cuenca Neuquina (Argentina): nueva propuesta de ordenamiento litoestratigráfico. Revista del Museo Argentino de Ciencias Naturales 12 (2), 121-177.

Garrido, A.C., Calvo, J.O., 2004. Reasignación litoestratigráfica de los niveles portadores de Megaloolithus patagonicus Calvo et al. (Dinosauria: Sauropoda) en las bardas de la ciudad de Neuquén. Ameghiniana (Suplemento) 41 (4), 47R.

Gasparini, Z.B., Chiappe, L.M., Fernández, M., 1991. A new Senonian peirosaurid (Crocodylomorpha) from Argentina and a synopsis of the South American Cretaceous crocodilians. Journal of Vertebrate Paleontology 11, 316-333.

Gasparini, Z., Sterli, J., Parras, A., O'Gorman, J.P., Salgado, L., Varela, J., Pol, D., 2015. Late Cretaceous reptilian biota of the La Colonia Formation, central Patagonia, Argentina: occurrences, preservation and paleoenvironments. Cretaceous Research 54, 154-168.

González Riga, B., Casadío, S., 2000. Primer registro de Dinosauria (Ornithischia, Hadrosauridae) en la provincia de La Pampa (Argentina) y sus implicancias paleobiogeográficas. Ameghiniana 37 (3), 341-351.

Heredia, S., Calvo, J.O., 1997. Sedimentitas eólicas en la Formación Río Colorado (Grupo Neuquén) y su relación con la fauna del Cretácico superior. Ameghiniana 34 (1), 120.

Heredia, S., Calvo, J.O., 2002. Estratigrafía de las bardas de la ciudad de Neuquén, Argentina. $1^{\circ}$ Congreso Geológico Argentino, Actas 699-705.

Hill, R.V., Pol, D., Rougier, G., Puerta, P., 2002. New dinosaur fossils from the Late Cretaceous La Colonia Formation Chubut Province, Argentina. Journal of Vertebrate Paleontology. Abstracts of papers. Sixtieth-one annual meeting Society of vertebrate paleontology, 22, Supplement to number $365 \mathrm{~A}$.

Horner, J.R., Weishampel, D.B., Forster, C.A., 2004. Hadrosauridae. In: Weishampel, D.B., Dodson, P., Osmólska, H. (Eds.), The Dinosauria. University of California Press, Berkeley, pp. 438-463.

Huene, F. Von, 1934. Nuevos dientes de Saurios del Cretáceo del Uruguay. Boletin Instituto Geologico del Uruguay 21, 13-20.

Hugo, C.A., Leanza, H.A., 2001. Hoja Geológica 3069-IV General Roca (escala 1: 250.000). Provincias de Río Negro y Neuquén. Instituto de Geología y Recursos Minerales. SEGEMAR. Boletín 308, 1-65.

Ibiricu, L.M., Martínez, R.D., Lamanna, M.C., Casal, G., Luna, M., Harris, J., Lacovara, K.J., 2010. A medium sized Ornithopod (Dinosauria: Ornithischia) from the Upper Cretaceous Bajo Barreal Formation of Lago Colhué Huapi, Southern Chubut province, Argentina. Annals of the Carnegie Museum 79, 29-40.

Ibiricu, L.M., Martínez, R.D., Luna, M., Casal, G.A., 2014. A reappraisal of Notohypshilophodon comodorensis (Ornithischia, Ornithopoda) from the Late Cretaceous of Patagonia, Argentina. Zootaxa 3786 (4), 401-422.

Jaillard, E., Cappetta, J., Ellenberg, P., Feist, M., Grambast-Fessard, N., Lefranc, J.P., Sigé, B., 1993. Sedimentology, paleontology, biostratigraphy and correlation of the Late Cretaceous Vilquechico Group of Southern Peru. Cretaceous Research 14, 623-661.

Juárez Valieri, R.D., Haro, J.A., Fiorelli, L.E., Calvo, J.O., 2010. A new hadrosauroid (Dinosauria: Ornithopoda) from the Allen Formation (Late Cretaceous) of Patagonia, Argentina. Revista Museo Argentino de Ciencias Naturales, nueva serie 12 (2), 217-231.

Keidel, J., 1925. Sobre la estructura tectónica de las capas petrolíferas en el oriente del Territorio del Neuquén. Ministerio de Agricultura. Dirección General de Minería y Geología, Publicación 8, 5-67.

Lapparent de Broin, F. de, de la Fuente, M.S., 2001. Oldest world Chelidae (Chelonii, Pleurodira), from the Cretaceous of Patagonia. Comptes Rendues Académie des Sciences de Paris 333, 463-470.

Leanza, H.A., Apesteguía, S., Novas, F.E., de la Fuente, M., 2004. Cretaceous terrestrial beds from the Neuquén Basin (Argentina) and their tetrapod assemblages. Cretaceous Research 25, 61-87.

Legarreta, L., Gulisano, C.A., 1989. Análisis estratigráfico secuencial de la Cuenca Neuquina (Triásico superior - Terciario inferior). In: Chebli, G., Spalletti, L. (Eds.), Cuencas Sedimentarias Argentinas. INSUGEO, Serie Correlación Geológica, 6, pp. 221-243.

Legarreta, L., Kokogian, D.A., Boggetti, D.A., 1989. Depositional sequences of the Malargüe Group (Upper Cretaceous-Lower Tertiary), Neuquen Basin, Argentina. Cretaceous Research 10, 337-356.
Luna, M., Casal, G., Martínez, R., Lamanna, M., Ibiricu, L., Ivany, E., 2003. La presencia de un Ornithopoda (Dinosauria: Ornithischia) en el Miembro Superior de la Formación Bajo Barreal (Campaniano-Maastrichtiano?) del sur del Chubut. Ameghiniana XIX Jornadas Argentinas de Paleontología de Vertebrados. Buenos Aires, Ameghiniana 40(4) Suplemento 61R.

Makovicky, P.J., Kilbourne, B.M., Sadleir, R.W., Norell, M.A., 2011. A new basal ornithopod (Dinosauria, Ornithischia) from the Late Cretaceous of Mongolia. Journal of Vertebrate Paleontology 31 (3), 626-640.

Malumian, N., Carames, A., 1995. El Daniano marino de Patagonia (Argentina): paleobiogeografía de los foraminíferos bentónicos. In: Nañez, C. (Ed.), Paleógeno de América del Sur. Publicación Especial de la Asociación Palaeontológica Argentina, 3, pp. 83-105.

Marsh, O.C., 1881. Classification of the Dinosauria. American Journal of Science (ser. 3) $23,81-86$.

Martinelli, A.G., Forasiepi, A.M., 2004. Late Cretaceous vertebrates from Bajo de Santa Rosa (Allen Formation), Rio Negro province, Argentina, with the description of a new sauropod dinosaur (Titanosauridae). Revista Museo Argentino de Ciencias Naturales, nueva serie 6 (2), 257-305.

Martinelli, A.G., Pais, D.F., 2008. A new baurusuchid crocodyliform (Archosauria) from the Late Cretaceous of Patagonia (Argentina). Comptes Rendus Paleovol 7 (6), 371-381.

Martinelli, A.G., Vera, E.I., 2007. Achillesaurus manazzonei, a new alvarezsaurid theropod (Dinosauria) from the Late Cretaceous Bajo de la Carpa Formation, Río Negro Province, Argentina. Zootaxa 1582, 1-17.

Martinelli, A.G., Sertich, J.J.W., Garrido, A.C., Praderio, Á.M., 2012. A new peirosaurid from the Upper Cretaceous of Argentina: implications for specimens referred to Peirosaurus torminni Price (Crocodyliformes: Peirosauridae). Cretaceous Research 37, 191-200.

Martínez, R.D., 1998. Notohypsilophodon comodorensis, gen. et sp. nov., un Hypsilophodontidae (Ornithischia: Ornithopoda) del Cretacico Superior de Chubut, Patagonia central, Argentina. Acta Geologica Leopoldensia 21 (46/47), 119-135.

Méndez, A.H., Filippi, L.S., Garrido, A.C., 2015. Nuevos hallazgos de dinosaurios terópodos provenientes del sitio La Invernada (Formación Bajo de la Carpa), Rincón de los Sauces, Neuquén. Ameghiniana 52 (4) Suplemento 2015-Resúmenes 28-29.

Molnar, R., 1980. Australian Late Mesozoic terrestrial tetrapods: some implications. Mémoire Société géologique de France, N.S. 139, 131-143.

Moreno, K., Carrano, M.T., Snyder, R., 2007. Morphological changes in pedal phalanges through ornithopod dinosaur evolution: a biomechanical approach. Journal of Morphology 268 (1), 50-63.

Norman, D.B., Sues, H.-D., Witmer, L.M., Coria, R.A., 2004. Basal Ornithopoda. In: Weishampel, D.B., Dodson, P., Osmólska, H. (Eds.), The Dinosauria. University of California Press, Berkeley, pp. 393-412.

Novas, F.E., 2009. The Age of Dinosaurs in South America. Indiana University Press, Indiana, pp. 1-536.

Novas, F.E., Cambiaso, A.V., Ambrosio, A., 2004. A new basal iguanodontian (Dinosauria, Ornithischia) from the Upper Cretaceous of Patagonia. Ameghiniana 41, $75-85$.

Owen, R., 1842. Report on British fossil reptiles. Part II. Report of Eleventh Meeting of the British Association of the Advancement of Science, XI 60-204.

Parras, A., Casadıo, S., Pires, M., 1998. Secuencias depositacionales del Grupo Malargüe (límite Cretácico-Paleógeno), sur de la provincia de Mendoza, Argentina. Asociación Paleontológica Argentina, Publicación Especial 5 "Paleógeno de América del Sur y de la Península Antártica, Buenos Aires $181-192$.

Porfiri, J.D., Calvo, J.O., 2002. A new record of an ornithopod dinosaur from the Upper Cretaceous of Neuquén, Patagonia, Argentina. Primer Congreso Latinoamericano de Paleontología de Vertebrados (Santiago de Chile, 2002), Resúmenes, 45.

Prieto-Marquez, A., Salinas, G.C., 2010. A re-evaluation of Secernosaurus koerneri and Kritosaurus australis (Dinosauria, Hadrosauridae) from the Late Cretaceous of Argentina. Journal of Vertebrate Paleontology 30 (3), 813-837.

Roth, S., 1898. Apuntes sobre la geología y paleontología de los territorios del Río Negro y Neuquén. Revista Museo de La Plata 9, 1-56.

Rozadilla, S., Agnolin, F.L., Novas, F.E., Aranciaga Rolanda, A.M., Motta, M.J. Lirio, J.M., Isasi, M.P., 2016. A new ornithopod (Dinosauria, Ornithischia) from the Upper Cretaceous of Antarctica and its palaeobiogeographical implications. Cretaceous Research 57, 311-324.

Salgado, L., Coria, R.A., Heredia, S.E., 1997. New materials of Gasparinisaura cincosaltensis (Ornithischia, Ornithopoda) from the Upper Cretaceous of Argentina. Journal of Paleontology 71 (5), 933-940.

Salgado, L., Canudo, J.I., Garrido, A.C., Ruiz-Omeñaca, J.I., García, R.A., de la Fuente, M.S., Barco, J.L., Bollati, R., 2009. Upper Cretaceous vertebrates from "El Anfiteatro" (Río Negro, Patagonia, Argentina). Cretaceous Research 30, 767-784.

Sánchez, M.L., Gómez, M.J., Heredia, S., 2006. Sedimentología y paleoambientes del Subgrupo Río Colorado (Cretácico Superior), Grupo Neuquén, en las bardas de la ciudad de Neuquén y alrededores. Revista de la Asociación Geológica Argentina 61 (2), 236-255.

Seeley, H.G., 1887. The classification of Dinosauria. Geological Magazine, Series 3, 4562.

Smith Woodward, A.S., 1896. On two Mesozoic crocodilians Notosuchus nov. gen. and Cynodontosuchus nov. gen. from the red sandstones of the Territory of Neuquén (Argentina). Anales del Museo de la Plata. Paleontología 4, 1-20. 
Smith Woodward, A.S., 1901. On some extinct reptiles from Patagonia of the genera Miolania, Dinilysia and Genyodectes. Proccedings of the Royal Society of London $1,169-184$.

Valentin, J., 1897. Bosquejo Geológico de la Argentina. In: Latzina, F. (Ed.), Diccionario Geográfico de la República Argentina. $3^{\circ}$ Edición: Gmo. Van Woerden and Cia., Sucesores de Ernst Nolte, Buenos Aires, 50 pp.

Wagner, J.R., 2001. The hadrosaurian dinosaurs (Ornithischia: Hadrosauria) of Big Bend National Park, Brewster County, Texas, with implicatications for Late Cretaceous paleozoogeography. Texas Tech University. M.S. Thesis, 417pp.
Wichmann, R., 1916. Las capas con dinosaurios en la costa sur del Río Negro, frente a General Roca. Physis 2 (11), 258-262.

Windhausen, A., 1922. Estudios geológicos en el valle superior del Río Negro. Dirección de Minas, Geología e Hidrogeología. Boletín № 29, 1-56.

Wright, J.L., 2004. Bird-like features of dinosaur footprints. Feathered Dragons. Indiana University Press, Bloomington and Indianapolis, Indiana, pp. 167-181.

Zheng, W.J., Jin, X.S., Shibata, M., Azuma, Y., Yu, F.M., 2012. A new ornithischian dinosaur from the Cretaceous Liangtoutang Formation of Tiantai, Zhejiang Province, China. Cretaceous Research 34, 208-219. http://dx.doi.org/10.1016/ j.cretres.2011.11.001. 